\title{
ANALISIS KUALITAS PELAYANAN \\ ADMINISTRASI AKADEMIK DENGAN \\ 40 \\ METODE IMPORTANCE PERFORMANCE \\ ANALYSIS (IPA) (STUDI FAKULTAS EKONOMI \\ UNIVERSITAS BHAYANGKARA JAKARTA RAYA)
}

\author{
Ami Lestari' ${ }^{1}$ Dhian Tyas Untari² \\ Fakultas Ekonomi Universitas Bhayangkara Jakarta Raya ${ }^{1,2}$ \\ ami.lestari@yahoo.com¹ ${ }^{1}$ dhian.ta@yahoo.com²
}

\begin{abstract}
ABSTRAK
Penelitian ini dilakukan untuk menganalisis kualitas kesenjangan antara presepsi dan harapan mahasiswa terhadap kualitas pelayanan administrasi akademik yang diberikan Fakultas Ekonomi Universitas Bhayangkara Jakarta Raya. Penelitian ini menggunakan metode pendekatan kuantitatif deskriptif. Populasi dalam penelitian ini adalah mahasiswa Program Studi Manajemen Fakultas Ekonomi UBJ 40eknik40n 2015. Pengambilan Sampel dalam penelitian ini menggunakan 40eknik Purposive Sampling dengan jumlah responden 139 orang. Teknik pengumpulan data menggunakan angket. Analisis yang digunakan adalah Gap Analysis dan Importance Performance Analysis (IPA). Hasil penelitian menunjukan bahwa dilihat dari analisis tingkat kesesuaian dan analisis kesenjangan berdasarkan dari lima dimensi SERVQUAL, kualitas pelayanan administrasi akademik pada Fakultas Ekonomi Universitas Bhayangkara memiliki 1 dimensi yang harapannya lebih besar dibandingkan kinerja yang diberikan yaitu dimensi Daya Tanggap (Responsibility). Berdasarkan pemetaan atribut diagram kertasius terdapat satu atribut yang dianggap penting oleh mahasiswa dan perlu tindakan prioritas yaitu atribut ketanggapan karyawan dalam membantu mahasiswa.
\end{abstract}

Kata Kunci: Kualitas Pelayanan administrasi akademik, Gap Analisis, IPA, SERVQUAL

ANALYSIS OF ACADEMIC ADMINISTRATION QUALITY SERVICES USING IMPORTANCE PERFORMANCE ANALYSIS (IPA) METHOD (STUDY OF ECONOMIC FACULTY OF BHAYANGKARA JAKARTA RAYA UNIVERSITY)

\section{ABSTRACT}

This study was conducted to analyze the quality of the gap between students' perceptions and expectations of the quality of academic administrative services provided by the Faculty of Economics, Bhayangkara University, Greater Jakarta. This research uses a descriptive quantitative approach. The population in this study were students of the Management Study Program of the Faculty of Economics UBJ 2015. Sampling in this study used purposive sampling technique with 139 respondents. Data collection techniques using a questionnaire. The analysis used is Gap Analysis and Importance Performance Analysis (IPA). The results showed that seen from the analysis of the suitability level and gap analysis 
based on the five SERVQUAL dimensions, the quality of academic administrative services at the Faculty of Economics, University of Bhayangkara has one dimension that is expected to be greater than the performance given, namely the Responsibility dimension. Based on the mapping of the attribute diagram of the paper there is one attribute that is considered important by students and needs priority action, that is the attribute of employee responsiveness in helping students.

\section{Keywords: Service Quality of academic administration, Gap Analysis, Science, SERVQUAL}

Diterima: 15 Agust 2019; Direvisi: 16 Sept 2019; Diterbitkan: 30 Okt 2019

\section{PENDAHULUAN}

Perkembangan dunia pendidikan pada saat ini tergolong dalam keadaan maju dimana tidak hanya dilihat dari bagaimana seorang pengajar tersebut mentransfer pengetahuan yang dimilikinya namun dilihat juga bagaimana para peserta didik mampu menerima pengetahuan yang diberikan tersebut. Menurut Menteri Pendidikan dan Kebudayaan (Mendikbud) Muhadjir Effendy dalam Sindo News (2017) "Sektor pendidikan di Indonesia telah mengalami kemajuan yang signifikan. Salah satu indikatornya adalah sebanyak 72,3\% anak usia dini di Indonesia telah mengikuti proses pendidikan" (diakses tanggal 17 Februari 2019). Bidang pendidikan juga menjadi sebuah ajang persaingan hal ini di karena kan semakin banyaknya perguruan tinggi di Indonesia yang mulai memberikan pelayanan yang baik kepada mahasiswa maupun calon mahasiswa, dengan maksud perguruan tinggi tersebut mampu memenangkan persaingan tersebut.

Total Jumlah Perguruan tinggi di Indonesia saat diakses pada tanggal 17 Februari 2019 sebesar 4.693 dengan jumlah 1.018 Akademi, 292 Politeknik, 2.552 Sekolah Tinggi, 227 Institut, 604 Universitas. Sebagai suatu lembaga penyedia jasa pendidikan dituntut dapat memberikan pelayanan yang mampu menciptakan kepuasan maksimal kepada masyarakat pengguna jasanya, yang pada gilirannya justru akan mampu mendorong kemajuan Perguruan Tinggi tersebut. Dalam hal ini, salah satu ukuran kinerja penting pada perguruan tinggi adalah kepuasan yang dirasakan oleh mahasiswa terkait dengan program dan pelayanan yang diberikan. Perguruan tinggi termasuk ke dalam kelompok jasa murni, di mana pemberian jasa yang dilakukan didukung oleh personel dan fasilitas.

Seperti yang dikatakan oleh Kotler (2006:105) dalam Rahareng dan Relawan (2017:126) menyatakan bahwa "Salah satu cara menempatkan sebuah perusahaan jasa lebih unggul daripada pesaingnya ialah dengan memberikan pelayanan yang lebih bermutu dibandingkan dengan para pesaingnya”. Pengelolaan kualitas layanan yang baik dan benar dapat menjadi daya tarik bagi mahasiswa. Dalam kegiatannya, Perguruan Tinggi harus mampu mengelola sistem mutu layanan maupun administrasinya. Ruang lingkup yang seperti ini akan menghasilkan sebuah sistem layanan yang transparan, tepat waktu, tepat jumlah dan tepat mutu. Apabila aspek-aspek seperti itu dilaksanankan dengan baik maka akan menimbulkan image keterpercayaan (reliability) dan keterjaminan (assurance) yang mencakup: keterpercayaan terhadap penyelenggaraan, ketepatan waktu pendidikan, dan keterjaminan berhasilnya pendidikan (Lupiyoadi 2008: 163) dalam Rahareng dan Relawan (2017:126). Dari ketiga aspek tersebut akan merefleksikan sejauh mana mutu layanan dan manajemen dari Perguruan Tinggi tersebut. 
Dapat dilihat bahwa perguruan tinggi sebagai salah satu pengelola jasa juga harus memperhitungkan tingkat kepuasan konsumennya agar mampu menjalankan kegiatan perkuliahan dengan baik.

Sebagai upaya mewujudkan layanan pendidikan yang lebih baik setiap institusi perguruan tinggi yang sudah dapat penilaian reputasi yang baik dari masyarakat diharapkan dapat menjaga kredibilitas tersebut melalui upaya berkelanjutan menjaga kinerja kualitas layanan pendidikan. Kinerja kualitas layanan yang baik diharapkan dapat memenuhi harapan mahasiswa sebagai konsumen utama dan jika harapannya terpenuhi maka kepuasan mahasiswa dapat terpenuhi. Jadi dapat dikatakan bahwa kepuasan mahasiswa terkait erat dengan kesesuaian antara harapan dan kenyataan dari kualitas layanan pendidikan yang didapat di tempatnya melanjutkan studi. Salah satu strategi yang dapat dilakukan untuk menjaga kualitas layanan adalah dengan melakukan evaluasi kualitas layanan dengan tujuan untuk mengetahui apakah terdapat perbedaan atau tidak antara kualitas layanan yang diharapkan mahasiswa dengan kualitas layanan yang diterima (Rosi, 2015).

Universitas Bhayangkara Jakarta Raya memiliki 6 fakultas, salah satunya adalah Fakultas Ekonomi. Fakultas Ekonomi memiliki jumlah mahasiswa sebanyak 1.492 untuk Program Studi Manajemen dan 703 Mahasiswa untuk Program Studi Akuntansi. Sedangkan staff yang menangani mahasiswa FE UBJ sebanyak 5 staff karyawan.

Sebagai institusi pendidikan di bawah naungan nama besar Universitas Bhayangkara Jakarta Raya (UBJ), Program Studi Manajemen Fakultas Ekonomi UBJ sudah pasti juga harus dapat menjadi bagian dari UBJ yang secara nyata mampu memberikan apa yang menjadi kebutuhan mahasiswa sebagai pelanggan utama melalui kinerja proses layanan terbaik demi upaya terus terjaga mutu pendidikan yang berkualitas dan berkelanjutan. Selain memiliki ancaman persaingan dengan pergurun tinggi yang membuka program sejenis lainnya, Program Studi Manajemen juga harus mampu berdaya saing dengan program studi yang berada di UBJ.

Peningkatan pelayanan merupakan faktor yang sangat penting, jasa bila tidak didukung dengan pelayanan yang tepat maka akan berakibat ketidakpuasan oleh karena itu peningkatan kualitas pelayanan sangat diperlukan agar kepuasan mahasiswa terpenuhi, Pelayanan administrasi akademik yang berkualitas memberikan dorongan bagi mahasiswa untuk menjalin ikatan yang saling menguntungkan dalam jangka panjang. Mahasiswa yang puas akan memberikan manfaat bagi institusi, misalnya mereka akan terus menggunakan jasa institusi tersebut dengan studi lanjut, mereka juga dapat mempromosikan kepada orang lain sehingga pada akhirnya akan meningkatkan citra dari institusi tersebut.

Dalam mengukur persepsi mahasiswa terhadap kualitas layanan di Fakultas Ekonomi Universitas Bhayangkara Jakarta Raya memang diperlukan adanya instrumen pengukuran yang tepat. Penulis menggunakan instrumen SERVQUAL yang diciptakan Parasuraman, Zeithml, dan Berry Model kualitas layanan ini paling populer dan hingga kini banyak dijadikan acuan dalam riset manajemen, dan dalam perkembangannya model SERVQUAL ini juga dijadikan acuan untuk mengukur kualitas layanan yang lebih spesifik di bidang jasa pendidikan.

Berdasarkan rumusan masalah di atas, tujuan penelitian ini adalah:

1. Untuk menganalisis kualitas kesenjangan antara persepsi dan harapan mahasiswa terhadap kualitas pelayanan akademik yang diberikan Fakultas Ekonomi Universitas Bhayangkara Jakarta Raya.

2. Untuk mengindentifikasi faktor kualitas layanan apa yang dianggap penting dengan menggunakan lima dimensi SERVQUAL.

3. Untuk memetakan prioritas perbaikan berdasarkan identifikasi faktor kualitas 
layanan yang dianggap paling penting oleh mahasiswa yang diharapkan dapat meningkatkan kualitas pelayanan Akademik Fakultas Ekonomi Universitas Bhayangkara Jakarta Raya.

\section{KAJIAN TEORETIK}

\section{Jasa}

Kotler, 1997 (dalam Djunaidi et al, 2006:26) mengatakan bahwa Jasa adalah setiap tindakan atau perbuatan yang dapat ditawarkan oleh suatu pihak kepada pihak yang lain, yang pada dasarnya bersifat intangible (tidak berwujud fisik) dan tidak menghasilkan kepemilikan sesuatu.

Menurut William J. Stanton yang dikutip oleh Alma (2003:2) Jasa adalah sesuatu yang dapat diidentifikasi secara terpisah tidak berwujud, ditawarkan untuk memenuhi kebutuhan. Jasa dapat dihasilkan dengan menggunakan benda-benda berwujud atau tidak. Selanjutnya, (Zethaml dan Bitner : 2000) dalam Alma (2013:243) memberikan pengertian jasa sebagai berikut "broad $n$ is one that defines service include all economic activities whose output is not a physical product or construction, is generally consumed at the time it is produced, and provides added value in form such as convenience, amusement,timeliness, comfort, or health)that are essentially intangible concerns of its first purchaser." " Jasa adalah suatu Kegiatan ekonomi yang outputnya bukan produk dikonsumsi bersamaan dengan waktu produksi dan memberikan nilai tambah (seperti kenikmatan, hiburan, santai, sehat) bersifat tidak berwujud.

Beberapa pengertian tersebut memberikan kesimpulan bahwa jasa adalah kegiatan ekonomi dengan hasil keluaran yang tidak berwujud yang ditawarkan dari penyedia jasa yaitu perusahaan kepada pengguna jasa atau konsumen. Pembedaan secara tegas antara barang dan jasa seringkali sukar dilakukan. Hal ini dikarenakan pembelian suatu barang seringkali disertai dengan jasa-jasa tertentu (pemberian garansi, pelatihan dan bimbingan operasional) dan sebaliknya pembelian suatu jasa seringkali juga melibatkan barang-barang yang melengkapinya (misalnya makanan di restoran, telepon dalam jasa telekomunikasi).

\section{Kualitas Jasa}

Lupiyoadi dan Hamdani (2008:175-181) dalam Yafie et al (2016: 13) menjelaskan bahwa kualitas jasa adalah sejauh mana jasa memenuhi spesifikasi-spesifikasinya. Salah satu pendekatan kualitas jasa adalah model SERVQUAL (Service Quality). Singkat kata, kualitas jasa didefinisikan sebagai seberapa jauh perbedaan antara kenyataan dan harapan pelanggan atas layanan yang mereka terima.

Menurut Tjiptono (2011:331) dalam Yafie et al (2016: 13) kualitas jasa berfokus pada upaya pemenuhan kebutuhan dan keinginan pelanggan serta ketepatan penyampaiannya untuk mengimbangi harapan pelanggan. Terdapat dua faktor utama yang mempengaruhi kualitas jasa, jasa yang diharapkan (expected service) dan jasa yang dipersepsikan (perceived service).

Berdasarkan beberapa definisi di atas dapat dikemukakan bahwa kualitas jasa merupakan tanggapan konsumen terhadap jasa yang dikonsumsinya. Apabila kualitas jasa yang diterima oleh konsumen lebih baik atau sama dengan yang ia bayangkan, maka ia cenderung akan mencobanya kembali. Akan tetapi, bila perceived services lebih rendah dari expected services, maka konsumen akan kecewa dan tidak akan melanjutkan hubungannya dengan perusahaan jasa yang bersangkutan.

\section{Pengukuran dan Penilaian Kualitas Jasa}

Pengukuran kualitas suatu jasa atau produk menurut Fandy Tjiptono (2001:46) dalam Kaihatu (2008:70) dapat diperoleh melalui pengukuran atas kepuasan pelanggannya yang ditunjukkan melalui variabel harapan dan kinerja yang dirasakan pelanggan atau perceived performance.

Selanjutnya, Parasuraman, et al., (1988:12) mendefinisikan penilaian kualitas 
jasa sebagai sikap yang berhubungan dengan keunggulan suatu jasa pelayanan atau pertimbangan konsumen tentang keunggulan secara keseluruhan suatu perusahaan. Berdasarkan pemahaman diatas dapatlah dikatakan, bahwa pengukuran dan penilaian kualitas jasa tidaklah berbeda, akan tetapi dalam pelaksanaannya sedikit sulit dibandingkan pada produk fisik. Pada dasarnya inti dari pengukuran dan penilaian kualitas terletak pada dua sisi, yaitu dari sudut pandang konsumen dalam hal ini harapannya, dan disatu sisi terletak pada sudut pandang manajemen perusahaan.

Hal yang sama juga dikemukakan oleh Gronroos (1990) dalam Kaihatu (2008:70) menyatakan bahwa persepsi pelanggan terhadap kualitas total suatu jasa terdiri atas dua dimensi utama. Dimensi pertama, yakni technical quality (outcome dimension) yang berkaitan dengan kualitas output jasa yang dipersepsikan pelanggan. Dan dimensi kedua, yaitu functional quality (process-related dimension) berkaitan dengan kualitas cara penyampaian jasa atau menyangkut proses transfer kualitas teknis, output atau hasil akhir jasa dari penyedia jasa kepada pelanggan.

Dalam kebanyakan kasus, pelanggan dapat melihat dan mengetahui perusahaan, sumber daya, dan cara beroperasinya. Sebab itu, citra korporasi lokal (corporate local image) merupakan faktor utama dalam industri jasa. Faktor tersebut dapat mempengaruhi persepsi terhadap kualitas melalui berbagai cara. Jika penyedia jasa memiliki citra positif di dalam benak pelanggan, kesalahan kecil yang terjadi sangat mungkin untuk dimaklumi. Apabila kesalahan terjadi secara berulang, maka citra positif yang sudah dibangun akan rusak. Sebaliknya, jika citra organisasi sudah negatif terlebih dahulu, maka pengaruh atau efek dari setiap kesalahan yang dilakukannya kerapkali jauh lebih besar daripada citra positifnya.

\section{Kualitas Pelayanan}

Menurut Tjiptono (2007) dalam Panjaitan dan Yuliati (2016: 270) kualitas pelayanan merupakan upaya pemenuhan kebutuhan dan keinginan konsumen serta ketepatan penyampaiannya dalam mengimbangi harapan konsumen. Kualitas layanan menurut Kotler (2009 : 399) dalam Nugraha et al (2016:192) harus dimulai dari kebutuhan pelanggan dan berakhir dengan kepuasan pelanggan serta persepsi positif terhadap kualitas layanan.

Berry \& Parasuraman (2004:5) memberikan batasan tentang pengertian service quality is the foundation for service marketing because the core product being marketed is a performance of the product; the performance is what customer buy A strong service concept gives the companies the opportunity to compete for customer; a strong performance of the service concept built competitiveness by earning customer's strategy confidence and reinforcing branding, advertising, selling and pricing.

Artinya, kualitas pelayanan merupakan dasar bagi pemasaran jasa, karena inti produk yang dipasarkan adalah suatu kinerja (yang berkualitas), dan kinerjalah yang dibeli oleh pelanggan, oleh karena itu kualitas kinerja pelayanan merupakan dasar bagi pemasaran jasa. Konsep pelayanan yang baik akan memberikan peluang bagi perusahaan untuk bersaing dalam merebut konsumen. Sedangkan kinerja yang baik (berkualitas) dari sebuah konsep pelayanan menimbulkan situasi yang kompetitif dimana hal tersebut dapat diimplementasikan melalui strategi untuk meyakinkan pelanggan, memperkuat image tentang merek, iklan, penjualan, dan penentuan harga.

Tjiptono (2005:262) dalam Khoirista et al (2015:2) menyebutkan bahwa model kualitas jasa yang popular dan hingga kini banyak dijadikan acuan dalam riset pemasaran adalah model SERVQUAL (singkatan dari service quality) yang kembangkan oleh Parasuraman, Zeithaml, dan Berry. Servqual dibangun atas adanya perbandingan dua faktor utama yaitu 
persepsi pelanggan terima (perception service) dengan layanan yang sesungguhnya diharapkan (expected service).

\section{Dimensi Kualitas Pelayanan}

Model kualitas jasa yang sangat populer dan hingga kini banyak dijadikan acuan dalam riset pemasaran adalah Model SERVQUAL yang dikembangkan oleh Parasuraman, V.A. Zeithhaml, dan L.L. Berry. Model ini meliputi analisis terhadap lima kesenjangan (gap) yang berpengaruh terhadap kualitas jasa, sebagai penyebab kegagalan service delivery seperti yang tersaji pada Gambar 2.2. Adapun kelima kesenjangan yang dikutip oleh Fandy Tjiptono,( 2001:46-48) dalam Kaihatu (2008:71) yaitu:

1. Kesenjangan antara harapan konsumen dan persepsi manajemen. Manajemen tidak selalu dapat merasakan apa yang diinginkan oleh para pelanggan secara tepat.

2. Kesenjangan antara persepsi manajemen dan spesifikasi kualitas jasa. Mungkin manajemen mampu merasakan secara tepat apa yang diinginkan oleh para pelanggan, namun tidak menyusun suatu standar kinerja tertentu.

3. Kesenjangan antara spesifikasi jasa dan penyampaian jasa. Karyawan perusahan mungkin kurang dilatih atau bekerja melampaui batas dan tidak dapat dan tidak mau untuk memenihi standar.

4. Kesenjangan antara penyampaian jasa dan komunikasi eksternal. Harapan konsumen dipengaruhi oleh pernyataan-pernyataan yang dibuat oleh wakil (representative) dan iklan perusahaan.

5. Kesenjangan antara jasa yang dirasakan dan jasa yang diharapkan.

Lehtinen dan Lehtinen (1982) membagi dimensi kualitas jasa menjadi 3, yaitu: interactive quality yang berkenaan dengan contact person, physical quality yang berkenaan dengan fasilitas fisik yang mendukung kulitas jasa dan corporate quality yang melibatkan image perusahaan. (Babacus dan Boller, 1992) dalam (Munawaroh, 2005).

\section{Pelayanan Administrasi Akademik}

Pengertian layanan akademik dalam kurikulum pembelajaran menurut Rosita et al (2011:3) adalah upaya sistematis pendidikan untuk memfasilitasi peserta didik menguasai isi kurikulum melalui proses pembelajaran sehingga mereka mampu mencapai kompetensi standar yang diterapkan.

Kualitas pelayanan akademik merupakan perbandingan antara pelayanan akademik yang dirasakan pelanggan atau stakeholders dengan kualitas pelayanan akademik yang diharapkan pelanggan atau stakeholders (Pakpahan, 2004:47).

Apabila kualitas layanan akademik yang dirasakan sama atau melebihi kualitas pelayanan yang diharapkan maka pelayanan dikatakan berkualitas. Dengan kata lain, kualitas layanan akademik dapat pula diartikan sebagai kesesuaian dengan pencapaian pendidikan dan kompetensi pendidikan tingkat menengah pertama yang berkaitan dengan keseluruhan aktivitas yang dihasilkan dari produk dan layanan akademik sesuai dengan janji atau promosi yang direncanakan atau ditetapkan.

Institusi pendidikan sendiri sebagai suatu bentuk organisasi pendidikan tidak lepas adanya proses administrasi di dalamnya. Meskipun secara umum memiliki ciri yang sama, namun pada aplikasinya memiliki sistem prosedural yang berbeda dengan sistem administrasi di organisasi yang lain.

Kualitas pelayanan administrasi akademik perlu ditinjau dari beberapa hal yang berkenaan meliputi dasar, prinsip, klasifikasi dan proses dari administrasi akademik. Dalam penelitian ini lebih ditekankan pada tanggung jawab staff bagian administrasi akedemik program Manajemen Fakultas Ekonomi Universitas Bhayangkara yang berperan penting dalam kegiatan pelayanan administrasi perkuliahan mahasiswa, seperti halnya jadwal perkuliahan, nilai, informasi beasiswa, surat menyurat (legal formal), sehingga proses yang diharapkan dapat terlaksana dengan baik. Banyak orang mengartikan bahwa administrasi lebih merujuk kepada pekerjaan sekertaris, tata 
usaha atau pekerjaan yang berkaitan dengan tulis menulis. Namun lebih tepatnya, bahwa konotasi administrasi adalah upaya untuk mencapai tujuan secara efektif dan efisien dengan menemmpatkan orang-orang dalam suatu pola kerjasama. Instituti pendidikan sendiri sebagai suatu bentuk organisasi pendidikan tidak lepas dari adanya proses administrasi, meskipun secara umum memiliki ciri yang sama, namun pada aplikasinya memiliki sistem prosederural yang berbeda dengan sistem administrasi di organisasi yang lainnya.

Menurut Hadari Nawawi dalam Triono (2012:28) administrasi akademik adalah rangkaian kegiatan atau keseluruhan proses pengendalian usaha kerjasama sejumlah orang untuk mencapai tujuan secara berencana dan sistematis yang diselenggarakan dalam lingkungan tertentu, terutama berupa lembaga pendidikan formal. Kementerian pendidikan nasional mendefinisikan administrasi akademik adalah suatu proses, kegiatan bersama dalam akademik yang meliputi perencanaan, pengorganisasian, pengarahan, pengkoordinasikan, pengawasan, pembiyaan dan pelaporagn dengan menggunakan atau memanfaatkan fasilitas yang tersedia, baik personel, material, maupun spiritual untuk mencapai tujuan akdemik secara efektifitas dan efisien.

Kualitas pelayanan administrasi akademik tidak terlepas dari prinsip-prinsip akademik seperti yang mendeskripsikan oleh $\mathrm{H}$. M Daryanto dalam Triono (2012:29) sebagai berikut:

1. Prinsip efisiensi

2. Prinsip pengelolaan

3. Prinsip prioritas

4. Prinsip efektivitas kepemimpinan

5. Prinsip teamwork

\section{Kepuasan Pelanggan}

Kotler dan Keller (2009:138-139 dalam Panjaitan dan Yuliati (2016:270) mengungkapkan kepuasan adalah perasaan senang atau kecewa seseorang yang berasal dari perbandingan antara kesannya terhadap kinerja (atau hasil) suatu produk dan harapan harapannya.

Kepuasan adalah tanggapan terhadap pemenuhan keinginan konsumen.Ini adalah suatu penilaian bahwa fitur produk atau jasa, atau produk atau layanan itu sendiri, memberikan tingkat konsumsi yang menyenangkan terkait pemenuhan tersebut (Zeithaml, 2009:104) dalam Sigit \& Oktafani (2014).

Suprapti (2010:285) dalam Utami dan Jatra (2015:1998) menyatakan kepuasan pelanggan merupakan sikap keseluruhan yang diperlihatkan oleh pelanggan terhadap suatu produk setelah menggunakan atau mengkonsumsi produk itu. Dilihat dari perspektif manajerial, mempertahankan dan meningkatkan kepuasan pelanggan merupakan hal yang sangat penting.

Pada dasarnya kepuasan merupakan tingkat perasaan pelanggan setelah membandingkan antara kinerja layanan yang diterimanya dengan kinerja layanan yang diharapkannya. Ini berarti bahwa tingkat kepuasan merupakan fungsi dari perbedaan antara harapan dengan kinerja layanan.

Pelanggan yang merasa puas akan memberitahu orang lain tentang pengalaman mereka yang menyenangkan kepada orang lain, dan berpeluang besar untuk kembali menggunakan jasa yang sama dimasa yang akan datang, dengan kata lain pelanggan yang baik akan menjadi iklan yang baik untuk produk jasa yang telah digunakannya.

\section{Penelitian yang Relavan}

1. Rosi Setyorini (2015) dalam Thesis yang berjudul "Persepsi Mahasiswa Terhadap Kualitas Layanan Di Program Magister Sains Dan Doktor Fakultas Ekonomika Dan Bisnis Universitas Gadjah Mada: Penerapan Model Servqual Gap-5 Dan IPA". Penelitian ini 
bertujuan untuk mengetahui atribut kualitas pelayanan mana yang harus diperioritaskan. Teknik pengambilan sampel yang digunakan adalah Purposive sampling. Data dianalisis dengan menggunakan SERVQUAL dan Importance Performance Analysis. Hasil penelitian menunjukan bahwa 11 atribut (21\%) berada pada kuadran A, 18 atribut (35\%) ada pada kuadran B, 10 atribut (19\%) ada pada kuadran C, dan 13 atribut (25\%) ada pada kuadran D. Penelitian ini memiliki kesamaan dengan penelitian ini yaitu pada variabel kualitas pelayanan dan kepuasan mahasiswa, sedangkan perbedaannya terletak pada pengambilan sampel.

2. Theresia Ifi Wilis (2015) dalam Skripsi yang berjudul "Analisis Kualitas pelayanan dengan menggunakan gap analysis dan IPA pada restoran fusion food" Penelitian ini bertujuan untuk mengetahui kinerja atribut pelayanan dalam memenuhi kepuasan konsumen sehingga diperoleh usulan perbaikan. Data dianalisis dengan menggunakan SERVQUAL dan IPAAnalysis. Hasil penelitian menunjukan bahwa semua variabel kedua restoran bernilai negatif, dimana variabel assurance memiliki nilai negative terbesar yaitu -0,27. Penelitian ini memiliki kesamaan dengan yaitu pada metode analisis yang digunakan, sedangkan perbedaannya terletak pada sampel yang digunakan.

3. Penelitian yang dilakukan oleh Tutik Wahyuningsih, Sumarto dan Leny Noviani (2013) dalam jurnal yang berjudul "Kepuasan Mahasiswa FKIP UNS atas Kualitas Pelayanan Administrasi Akademik". Penelitian ini bertujuan untuk mengetahui tingkat kepuasan mahasiswa atas kualitas pelayanan administrasi akademik yang meliputi tangible, reability, responsiveness, assurance dan empaty. Penelitian ini merupakan penelitian deskriptif kuantitatif. Teknik pegambilan sampel yang digunakan adalah quota sampling. Data dianalisis dengan menggunakan analisis regresi linear ganda. Hasil penelitian menunjukan bahwa variabel kualitas pelayanan memiliki pengaruh simultan dan parsial terhadap kepuasan mahasiswa. Penelitian Tutik Wahyuningsih, dkk ini memiliki kesamaan dengan penelitian ini yaitu pada variabel kualitas pelayanan administrasi dan kepuasan, sedangkan perbedaannya terletak pada alat analisis dan teknik pengambilan sampel yang digunakan.

4. Penelitian yang dilakukan Muhammad Syahiddin, Dhian Tyas Untari dan Paryono dalam jurnal yang berjudul "Analysis of Tidung Island Tourist Perceptions and Preferences Using Importance Performance Analysis Method". Penelitian ini bertujuan untuk mengetahui Presepsi dan Preferensi wisatawan pada Pulau Tidung. Aspek dalam penelitian ini meliputi: produk, promosi, transportasi, harga dan layanan. Metode Important Performance Analysis (IPA) digunakan untuk menganalisis data. Hasil penelitian menunjukkan bahwa: Kebersihan dan penampilan situs masih dianggap kurang menarik oleh masyarakat, secara umum. Ada GAP antara persepsi preferensi wisatawan potensial dan wisatawan yang ada. Penelitian ini memiliki kesamaan dengan yaitu pada metode analisis yang digunakan, sedangkan perbedaannya terletak pada sampel yang digunakan.

\section{Kerangka Berpikir dan Hipotesis}




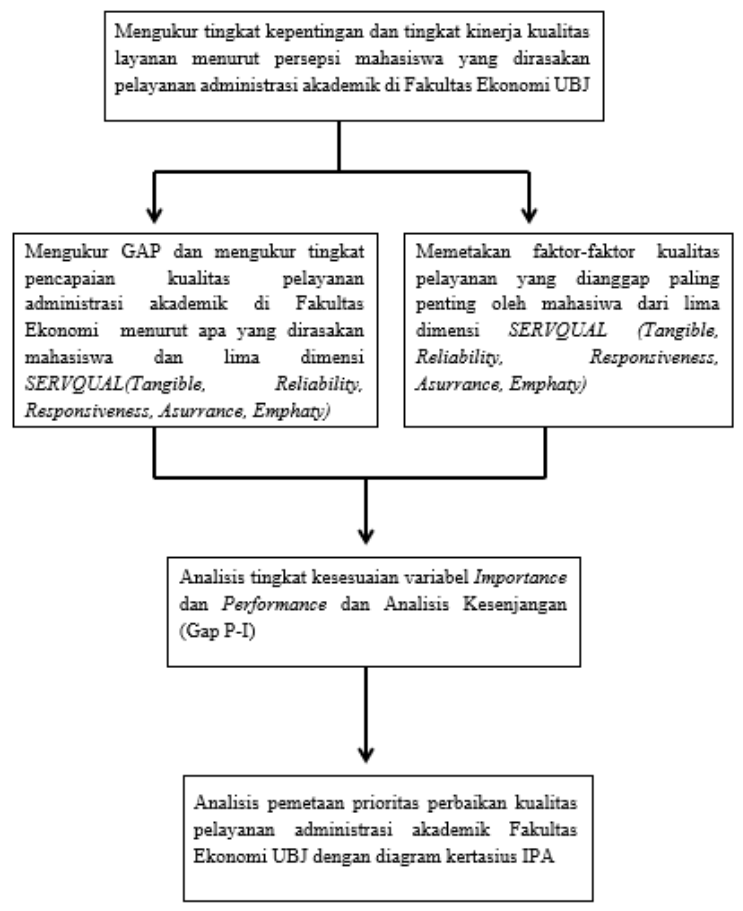

Gambar 3. Kerangka Berpikir

\section{Metode Penelitian}

Metode penelitian dalam penelitian ini adalah metode penelitian kualitatif dan kuantitatif dengan menggunakan teknik analisis statistik deskriptif. Model penelitian berfungsi untuk menggambarkan keterkaitan antar proses penelitian. Dalam penelitian ini, tingkat kualitas pengguna dilihat berdasarkan user-approach, yaitu pendekatan yang menyatakan bahwa produk/jasa yang berkualitas tinggi adalah produk yang memuaskan ekspektasi pengguna.

Model Importance Performance Analysis dapat diketahui ada dua atribut utama yang menentukan kepuasan pengguna yaitu expectation dan perceived performance. Expectation adalah harapan pengguna terhadap produk yang diinginkan. Sementara perceived performance adalah persepsi pengguna terhadap kinerja dari produk/produsen.
Sampling diperlukan sebagai bagian yang akan diteliti pada populasi yang mana sampel nantinya akan diproses dalam analisis data, hasilnya digeneralisasikan pada populasi tempat sampel diambil. Populasi dalam penelitian ini adalah mahasiswa program studi Pendidikan Ekonomi Fakultas Ekonomi Universitas Bhayangkara Jakarta yang masih aktif mengikuti perkuliahan dan hanya ditujukan untuk mahasiswa kelas A kelas B angkatan tahun 2015 yang berjumlah 213 orang dan dengan rumus Slovin diperoleh sample berjumlah 139 orang.

Analisis Tingkat Kesesuaian Importance dan Performance. Gap Analysis. Analisa gap dapat juga diartikan sebagai perbandingan kinerja aktual dengan kinerja potensial atau yang diharapkan. Dalam penelitian ini peneliti menggunakan gap ke dalam lima dimensi kualitas layanan. Analisis data dengan Metode Importance Performance Analysis (IPA).

\section{HASIL PENELITIAN DAN PEMBAHASAN}

Berdasarkan hasil penelitian dapat diketahui bahwa mahasiswa Program Studi Manajemen Fakultas Ekonomi yang terpilih sebagai responden sebanyak 139 orang dan tidak terbatas pada jenis kelamin tertentu. Data yang diperoleh melalui kuesioner yang diisi oleh responden menunjukan bahwa persentase responden pria sebesar 27,6\%, sedangkan persentase wanita sebesar $72,4 \%$ jadi dapat disimpulkan bahwa mayoritas responden dalam penelitian ini adalah wanita.

Terdapat 34 orang atau 32,4\% responden kelas 8B1, 32 orang atau 23\% responden kelas $8 \mathrm{~A} 1,20$ orang atau $14,4 \%$ responden kelas $8 \mathrm{~A} 3$, 20 orang atau $14,4 \%$ responden kelas $8 \mathrm{~A} 2,17$ orang atau $12,2 \%$ responden kelas $8 \mathrm{~B} 2,16$ orang atau $11.5 \%$ responden kelas $8 \mathrm{~B} 3$, yang keseluruhan merupakan Mahasiswa aktif angkatan 2015.

Tabel 1. 
70 | Jurnal Ilmiah Manajemen Ubhara, Volume 6 No 2, Oktober 2019. ISSN 1858 - 1358, E - ISSN 2684 - 7000

\section{Validitas Kuesioner Kinerja Pelayanan} Administrasi Akademik

\begin{tabular}{|c|c|c|c|c|}
\hline $\begin{array}{c}\text { Variabel Dimensi } \\
\text { Layanan }\end{array}$ & $\begin{array}{c}\text { Kode } \\
\text { Kuesioner }\end{array}$ & r Hitung & r Tabel & Keterangan \\
\hline \multirow{8}{*}{$\begin{array}{c}\text { Reliability } \\
(\mathbf{R e})\end{array}$} & & ,542 & 0,165 & Valid \\
\hline & $\operatorname{Re} 2$ & .593 & 0,165 & Valid \\
\hline & $\operatorname{Re} 3$ & .761 & 0,165 & Valid \\
\hline & $\operatorname{Re} 4$ & ,521 & 0,165 & Valid \\
\hline & $\operatorname{Re} 5$ & .668 & 0,165 & Valid \\
\hline & $\operatorname{Re} 6$ & .675 & 0,165 & Valid \\
\hline & $\operatorname{Re} 7$ & .705 & 0,165 & Valid \\
\hline & $\operatorname{Re} 8$ & 706 & 0,165 & Valid \\
\hline \multirow{5}{*}{$\begin{array}{l}\text { Responsiveness } \\
\text { (Res) }\end{array}$} & Res 9 & .771 & 0,165 & $\begin{array}{l}\text { Valid } \\
\text { Vlid }\end{array}$ \\
\hline & $\operatorname{Res} 10$ & 7,730 & 0,165 & Valid \\
\hline & $\operatorname{Res} 11$ & .675 & 0,165 & Valid \\
\hline & Res 12 & .750 & 0,165 & Valid \\
\hline & Res 13 & .776 & 0,165 & Valid \\
\hline \multirow{4}{*}{$\begin{array}{c}\text { Assurance } \\
\text { (Ass) }\end{array}$} & Ass 14 &, 739 & 0,165 & Valid \\
\hline & Ass 15 & .749 & 0,165 & Valid \\
\hline & Ass 16 & .812 & 0,165 & Valid \\
\hline & Ass 17 & .688 & 0,165 & \\
\hline \multirow{4}{*}{$\begin{array}{c}\text { Emphaty } \\
\text { (Emp) }\end{array}$} & Emp 18 & 794 & 0,165 & Valid \\
\hline & Emp 19 &, 758 & 0,165 & Valid \\
\hline & Emp 20 &, 775 & 0,165 & Valid \\
\hline & Emp 21 & .757 & 0,165 & Valid \\
\hline \multirow{4}{*}{$\begin{array}{c}\text { Tangible } \\
\text { (Tang) }\end{array}$} & Tang 22 & .697 & 0,165 & Valid \\
\hline & Tang 23 & 681 & 0,165 & Valid \\
\hline & Tang 24 & 330 & 0,165 & \\
\hline & Tang 25 & .724 & 0,165 & Valid \\
\hline
\end{tabular}


Tabel 2.

Validitas Kuesioner Kepentingan Pelayanan Administrasi Akademik

\begin{tabular}{|c|c|c|c|c|}
\hline $\begin{array}{c}\text { Variabel Dimensi } \\
\text { Layanan } \\
\text { Importance } \\
\end{array}$ & $\begin{array}{c}\text { Kode } \\
\text { Kuesioner }\end{array}$ & r Hitung & r Tabel & Keterangan \\
\hline \multirow{8}{*}{$\begin{array}{l}\text { Reliability } \\
\quad(\operatorname{Re})\end{array}$} & $\operatorname{Re} 1$ & ,750 & 0,166 & Valid \\
\hline & $\operatorname{Re} 2$ & 712 & 0,166 & Valid \\
\hline & $\operatorname{Re} 3$ & 824 & 0,166 & Valid \\
\hline & $\operatorname{Re} 4$ & 739 & 0,166 & Valid \\
\hline & $\operatorname{Re} 5$ & 779 & 0,166 & Valid \\
\hline & $\operatorname{Re} 6$ & 825 & 0,166 & Valid \\
\hline & $\operatorname{Re} 7$ & 789 & 0,166 & Valid \\
\hline & $\operatorname{Re} 8$ &, 748 & 0,166 & Valid \\
\hline \multirow{5}{*}{$\begin{array}{l}\text { Responsiveness } \\
\text { (Res) }\end{array}$} & $\operatorname{Res} 9$ & 849 & 0,166 & Valid \\
\hline & $\operatorname{Res} 10$ & 795 & 0,166 & Valid \\
\hline & $\operatorname{Res} 11$ & 861 & 0,166 & Valid \\
\hline & $\operatorname{Res} 12$ & 837 & 0,166 & Valid \\
\hline & Res 13 & 779 & 0,166 & Valid \\
\hline \multirow{4}{*}{$\begin{array}{c}\text { Assurance } \\
\text { (Ass) }\end{array}$} & Ass 14 & 867 & 0,166 & Valid \\
\hline & Ass 15 & 830 & 0,166 & Valid \\
\hline & Ass 16 & 844 & 0,166 & Valid \\
\hline & Ass 17 & 836 & 0,166 & Valid \\
\hline \multirow{4}{*}{$\begin{array}{l}\text { Emphaty } \\
\text { (Emp) }\end{array}$} & Emp 18 & 831 & 0,166 & Valid \\
\hline & Emp 19 & 885 & 0,166 & Valid \\
\hline & Emp 20 & 874 & 0,166 & Valid \\
\hline & Emp 21 & 855 & 0,166 & Valid \\
\hline \multirow{4}{*}{$\begin{array}{c}\text { Tangible } \\
\text { (Tang) }\end{array}$} & Tang 22 & ,786 & 0,166 & Valid \\
\hline & Tang 23 & 802 & 0,166 & Valid \\
\hline & Tang 24 & 668 & 0,166 & Valid \\
\hline & Tang 25 & .758 & 0,166 & Valid \\
\hline
\end{tabular}

Penelitian validitas dilakukan terhadap semua atribut pada bagian kinerja dan kepentingan pelanggan yang meliputi lima variabel yaitu pengujian validitas dilakukan terhadap semua atribut yang meliputi 5 variabel yaitu tangibles, reliability, responsiveness, assurance dan emphaty. Pengambilan keputusan item yang valid dengan cara membandingkan nilai hasil korelasi part whole (rbt) dengan taraf signifikan $5 \%$. Jika nilai rbt pada hasil analisis positif atau $\mathrm{p}<0,05$ maka item dinyatakan valid, sebaliknya jika nilai rbt pada hasil analisi negatif maka item tidak valid, dengan taraf signifikan $5 \%$ maka diperoleh nilai r tabel 0,166.

Berdasarkan hasil yang dapat dilihat pada lampiran, bahwa semua butir pertanyaan dalam kuesioner untuk pelayanan administrasi akademik semuanya valid. Hal ini dikarenakan nilai $r$ hitung dari masing-masing butir pertanyaan lebih besar atau sama dengan nilai $r$ tabel.
Tabel 3 .

Hasil Uji Reliabilitas Intrumen Pelayanan Administrasi Akademik

\begin{tabular}{|l|l|l|}
\hline \multicolumn{1}{|c|}{ Nama } & \multicolumn{1}{c|}{$\begin{array}{c}\text { Cronbach's } \\
\text { Alpha }\end{array}$} & \multicolumn{1}{c|}{ Keterangan } \\
\hline Kinerja &, 955 & Reliabel \\
\hline Kepentingan &, 977 & Reliabel \\
\hline
\end{tabular}

Berdasarkan tabel diatas, hal ini menunjukan bahwa semua item pertanyaan untuk mengukur variabel importance dan performance pelayanan pendidikan adalah reliabel karena mempuyai nilai alpha $>0,7$ sehingga instrumen dapat digunakan untuk penelitian berikutnya.

\section{Analisis Tingkat Kesesuaian Variabel Importance dan Performance}

Analisis tingkat kesesuaian dilakukan untuk mengetahui pencapaian kualitas kinerja layanan pendidikan yang diberikan di Fakultas Ekonomi UBJ berdasarkan penilaian mahasiswa.

Pengukuran tersebut dilakukan dengan menghitung perbandingan antara kenyataan atas layanan yang diterima dengan harapan atas layanan yang diinginkan. Hasil yang diperoleh adalah berupa tingkat kesesuaian pencapaian kualitas layanan adminstrasi akademik di di Fakultas Ekonomi UBJ.

Nilai dari tingkat kesesuaian yang diperoleh dari perbandingan antara kenyataan atas layanan yang diterima terhadap harapan dari mahasiswa tersebut menggambarkan kualitas kinerja layanan yang dinilai dalam bentuk persen kesesuaian. Berikut ini adalah perhitungan tingkat kesesuaian antara layanan pendidikan di adminstrasi akademik di Fakultas Ekonomi UBJ untuk masing-masing dimensi SERVQUAL. 
Tabel 4 .

Perhitungan Tingkat kesesuaian mutu layanan administrasi akademik dimensi Kehandalan

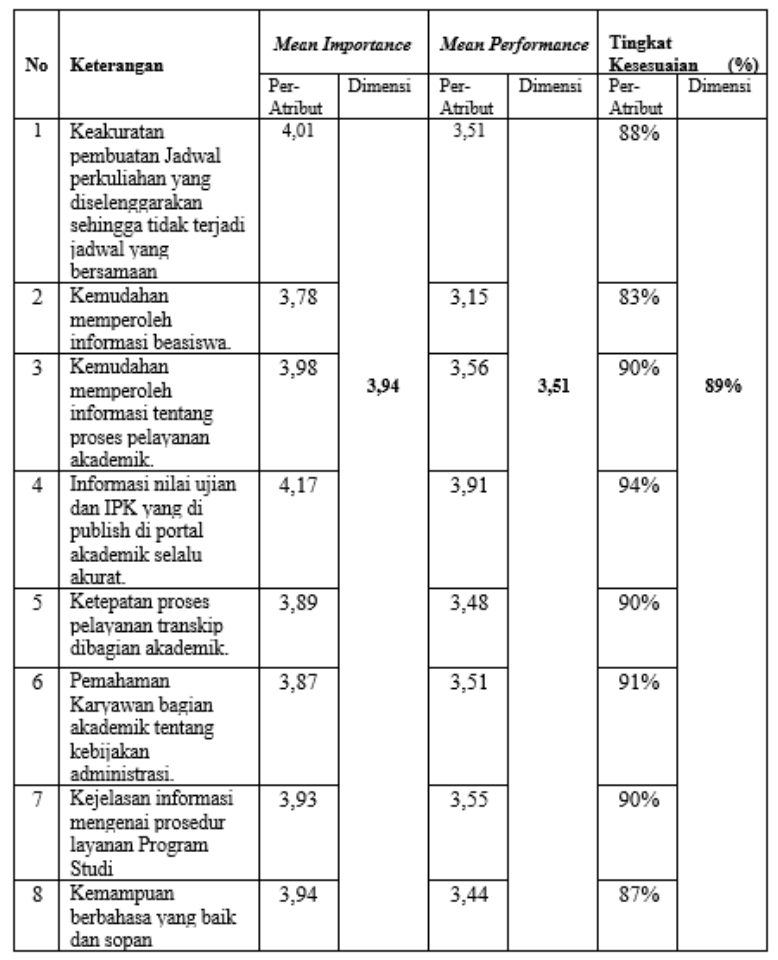

Kehandalan adalah kemampuan karyawan untuk melaksanakan pelayanan jasa secara akurat, kehandalan berhubungan dengan konsitensi kinerja,rata- rata persen kesesuaian dalam dimensi kehandalan karyawan administrasi akademik diperoleh sebesar 89\%. Atribut yang memperoleh persen kesesuaian terendah adalah Kemudahan memperoleh informasi beasiswa sebesar 83\%. Dan Atribut yang memperoleh persen kesesuaian tertinggi adalah Informasi nilai ujian dan IPK yang di publish di portal akademik selalu akurat sebesar 94\%.
Tabel 5 .

Perhitungan Tingkat Kesesuaian Mutu Layanan Administrasi Akademik Dimensi Daya Tanggap

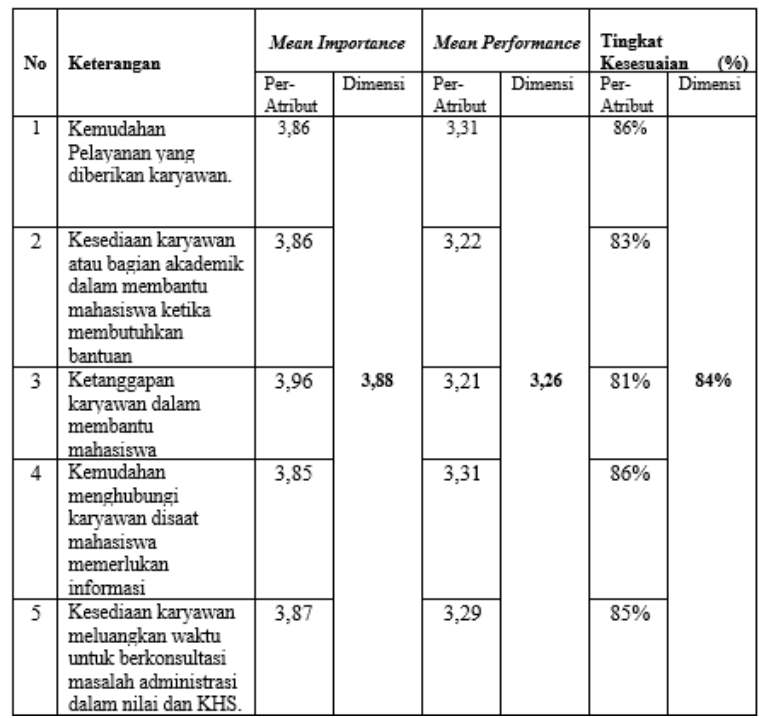

Kemampuan petugas administrasi untuk cepat tanggap dalam menghadapi masalah mahasiswa menjadi faktor penting, terkait pada tindakan proaktif yang dilakukan petugas sebelum adanya keluhan dari mahasiswa, hasil berdasarkan tabel 5 diatas menjelaskan bahwa rata-rata persen tingkat kesesuaian dari dimensi daya tanggap adalah sebesar 84\%, dengan atribut paling rendah persen kesesuaiannya sebesar $81 \%$ pada atribut ketanggapan karyawan dalam membantu mahasiswa. Sedangkan Atribut yang memperoleh persen kesesuaian tertinggi adalah Kemudahan Pelayanan yang diberikan karyawan dan Kemudahan menghubungi karyawan disaat mahasiswa memerlukan informasi dengan nilai persen kesesuaian sebesar $86 \%$. 
Tabel 6.

Perhitungan Tingkat Kesesuaian Mutu Layanan Administrasi Akademik Dimensi Empati

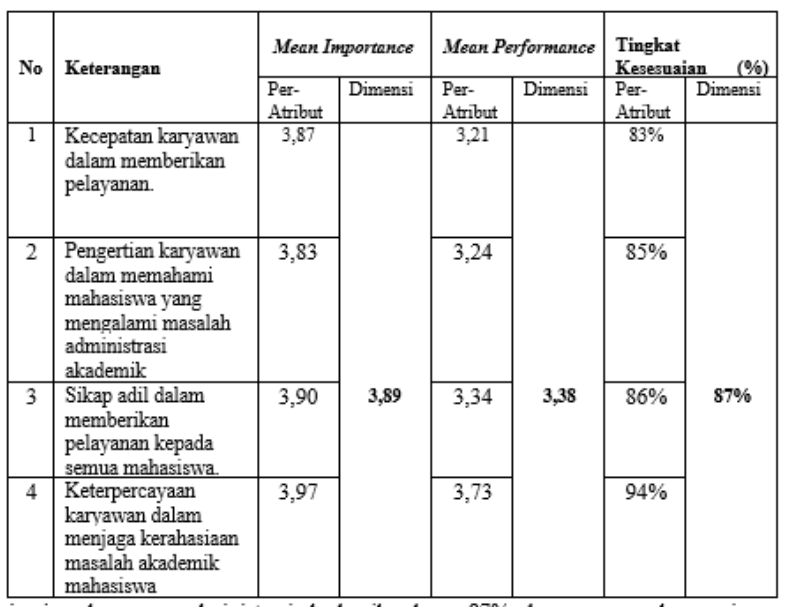

Berdasarkan tabel 4.6 diatas, Ratarata persen tingkat kesesuaian dimensi jaminan karyawan administrasi akademik sebesar $87 \%$, dengan persen kesesuaian terendah terdapat pada atribut kecepatan karyawan dalam memberikan pelayanan sebesar $83 \%$. Sedangkan Atribut yang memperoleh persen kesesuaian tertinggi adalah Keterpercayaan karyawan dalam menjaga kerahasiaan masalah akademik mahasiswa dengan nilai presentase kesesuaian sebesar $94 \%$.
Tabel 7 .

Perhitungan Tingkat Kesesuaian Mutu Layanan Administrasi Akademik Dimensi Empati

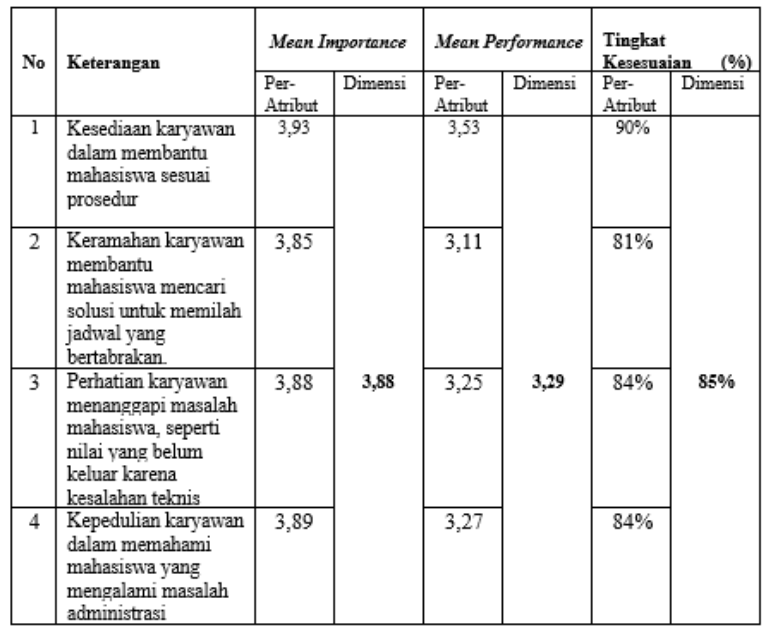

Berdasarkan tabel diatas rata-rata keseluruhan untuk dimensi empati sebesar $85 \%$. Atribut keramahan karyawan membantu mahasiswa mencari solusi untuk memilah jadwal yang bertabrakan merupakan atribut yang memiliki persen kesesuaian yang paling rendah dalam dimensi empati dengan persen kesesuaian sebesar 81\%. Sedangkan Atribut yang memperoleh persen kesesuaian tertinggi adalah Kesediaan karyawan dalam membantu mahasiswa sesuai prosedur dengan nilai presentase kesesuaian sebesar 90\%. 
Tabel 8.

Perhitungan Tingkat Kesesuaian Mutu Layanan Administrasi Akademik Dimensi Bukti Fisik

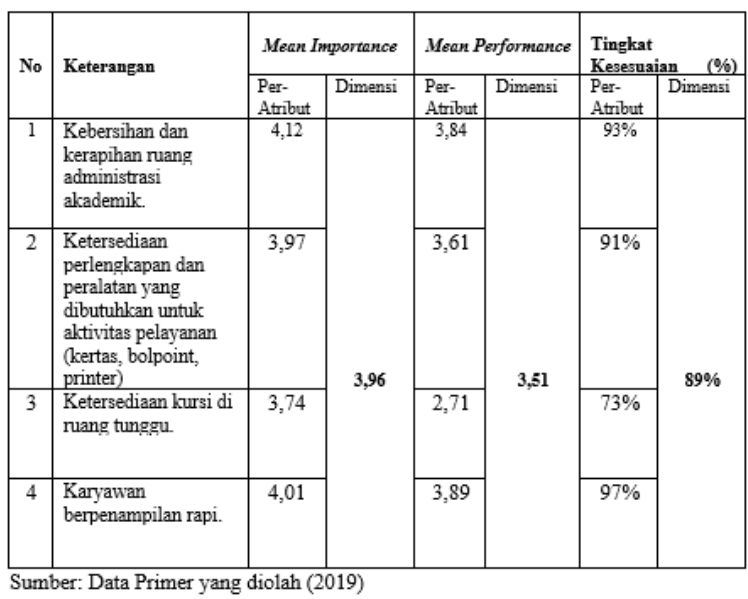

Rata-rata keseluruhan persen kesesuaian dari dimensi bukti fisik adalah sebesar 89\% berada dalam kategori baik karena nilai ratarata keseluruhan hampir menyentuh $90 \%$ dari keseluruhan rata-rata per dimensi. Dalam dimensi bukti fisik terdapat atribut yang masih di bawah rata-rata keseluruhan per item yaitu atribut ketersediaan kursi di ruang kursi sebesar $73 \%$, berlainan dengan atribut penampilan karyawan yang memiliki persen kesesuaian tertinggi mencapai $97 \%$.

Tabel 9.

Rata-rata Keseluruhan Perhitungan Tingkat Kesesuaian Mutu Layanan Administrasi Akademik Dari Kelima Dimensi SERVQUAL

\begin{tabular}{|l|c|c|c|}
\hline \multicolumn{1}{|c|}{ Dimensi } & $\begin{array}{c}\text { Mean } \\
\text { Importance }\end{array}$ & $\begin{array}{c}\text { Mean } \\
\text { Performance }\end{array}$ & $\begin{array}{c}\text { Tingkat } \\
\text { Kesesuaian (\%) }\end{array}$ \\
\hline Kehandalan & 3,94 & 3,51 & $89 \%$ \\
\hline Daya Tanggap & 3,88 & 3,26 & $84 \%$ \\
\hline Jaminan & 3,89 & 3,38 & $87 \%$ \\
\hline Empati & 3,88 & 3,29 & $85 \%$ \\
\hline Bukti Fisik & 3,96 & 3,51 & $89 \%$ \\
\hline $\begin{array}{l}\text { Rata-rata } \\
\text { Keseluruhan }\end{array}$ & $\mathbf{3 , 9 1}$ & $\mathbf{3 , 3 9}$ & $\mathbf{8 7 \%}$ \\
\hline \multicolumn{2}{|l|}{ Sumber: Data primer yang diolah (2019) } \\
\hline
\end{tabular}

\section{Analisis Gap Performance- importance (Gap P-I)}

Analisis kesenjangan kesenjangan antara harapan

merupakan mahasiswa terhadap kualitas layanan yang harusnya mereka terima dari pihak Fakultas Ekonomi dengan penilaian mahasiswa terhadap kualitas layanan yang telah mereka dapatkan ketika mereka merasakannya. Analisis kesenjangan ini dilakukan dengan menggunakan bantuan Microsoft Excel. Analigtsis kesenjangan ini dilakukan pada layanan karyawan administrasi akademik di Fakultas Ekonomi, analisis kesenjangan dilakukan berdasarkan model SERVQUAL yang ada. Analisis gap dalam penelitian ini dilakukan untuk tiga hal, yaitu analisis per item layanan, analisis per dimensi layanan dan analisis rata-rata keseluruhan. Hasil dari perhitungan gap P-I untuk masingmasing item, per dimensi maupun rerata keseluruhan dapat dilihat dalam tabel di halaman berikutnya.

Hasil perhitungan dari kesenjangan pada dimensi kehandalan diperoleh rata-rata keseluruhan item pada dimensi tersebut sebesar -o,43, dengan kesenjangan tertinggi berada pada atribut kemudahan memperoleh beasiswa dengan nilai sebesar -0,63. 
Tabel 10.

Perhitungan Gap Performance-Importance

(Gap P-I) Layanan Kinerja Karyawan Administrasi Akademik Dimensi Kehandalan

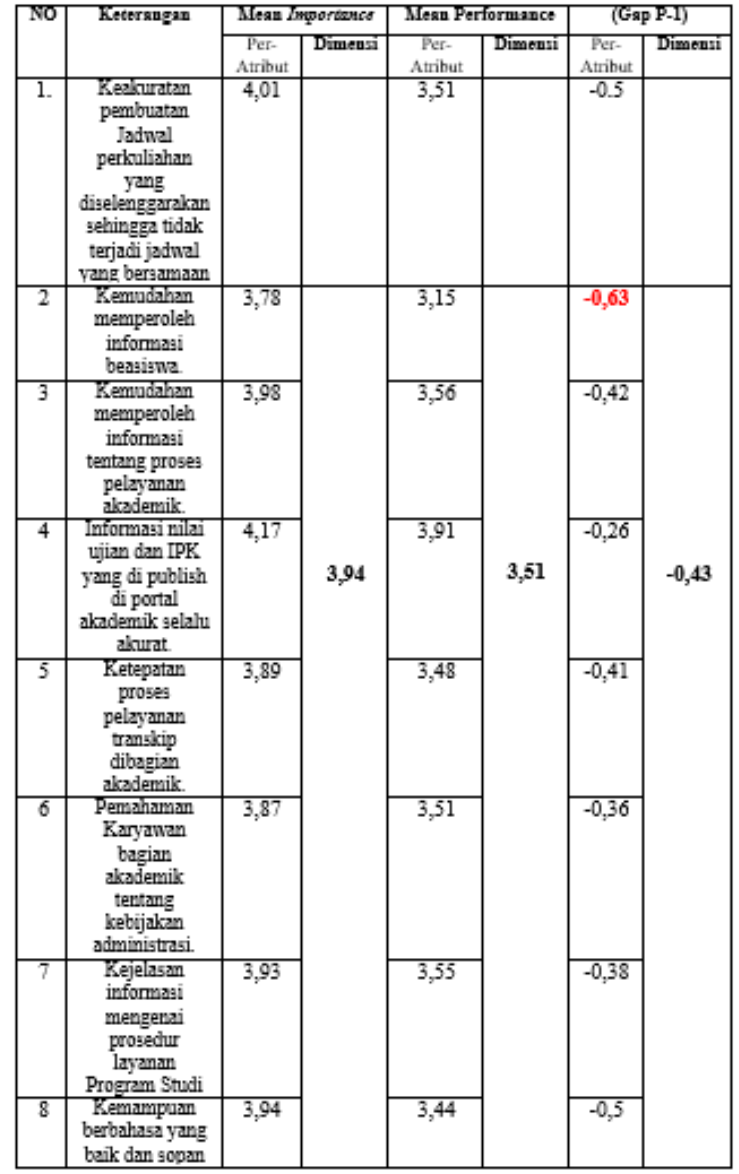

Berbeda dengan dimensi kehandalan, kesenjangan yang diperoleh dimensi daya tanggap lebih besar dibandingkan dengan kesenjangan dari dimensi kehandalan, kenyataanya hasil yang diperoleh masih negatif, rata-rata untuk seluruh item dimensi daya tanggap sebesar -0,62 dengan atribut yang memiliki kesenjangan tertinggi ada pada atribut ketanggapan karyawan sebesar -0,75.
Tabel 11

Perhitungan Gap PerformanceImportance (Gap P-I) Layanan Kinerja Karyawan Administrasi Akademik Dimensi Daya Tanggap

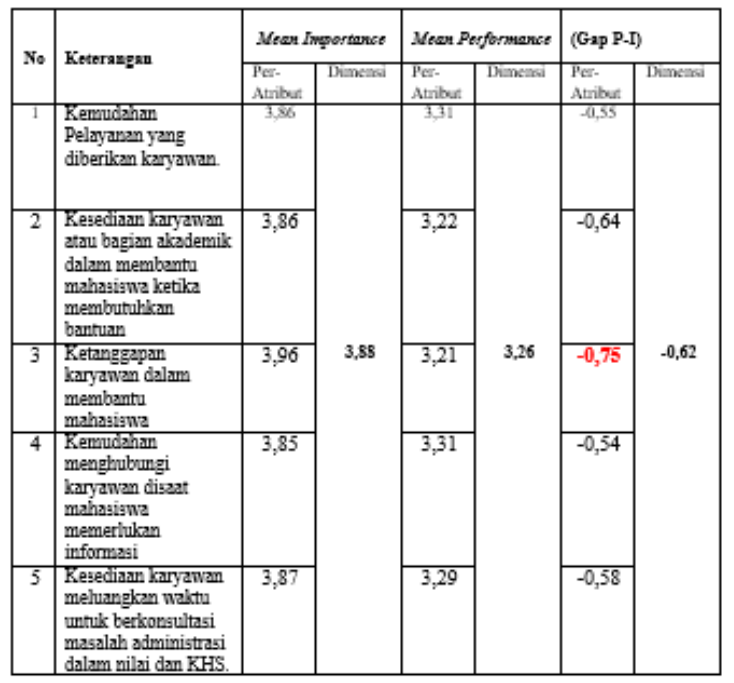

Tabel 12.

Perhitungan Gap Performance-Importance

(Gap P-I) Layanan Kinerja Karyawan Administrasi Akademik Dimensi Jaminan

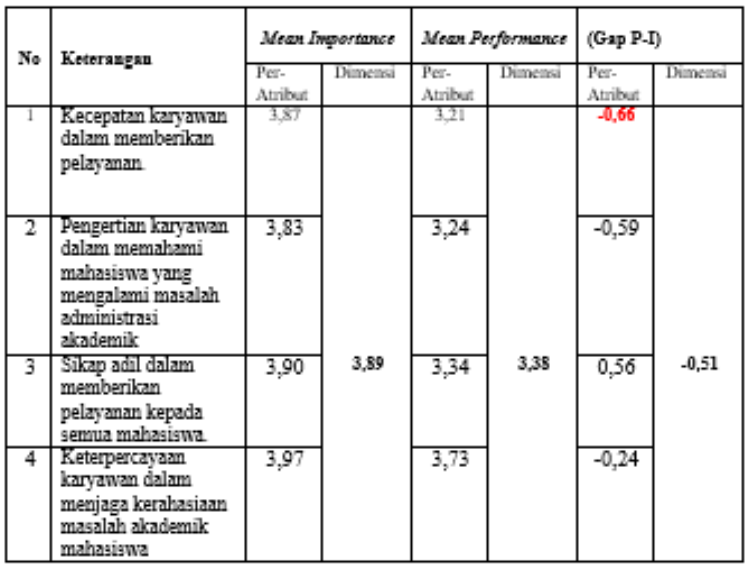

Berdasarkan tabel diatas, kecepatan karyawan dalam memberikan pelayanan terhadap mahasiswa merupakan atribut yang kenyataannya dijadikan prioritas penilaian oleh mahasiswa, dengan nilai kesenjangan yang diperoleh sebesar -o,66 menjadikan atribut tersebut harus memperoleh prioritas perbaikan dalam dimensi jaminan, sedangkan untuk rata- 
rata keseluruhan dari dimensi jaminan diperoleh nilai kesenjangan sebesar -0,51.

Tabel 13.

Perhitungan Gap Performance-Importance

(Gap P-I) Layanan Kinerja Karyawan Administrasi Akademik Dimensi Empati

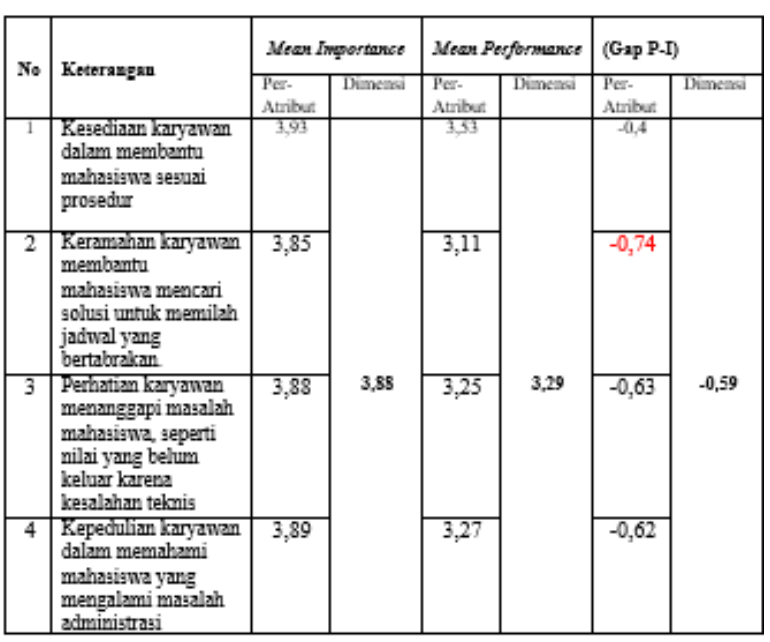

Empati adalah bentuk lain dari perhatian ataupun kepedulian, dalam hal ini karyawan administrasi akademik diharuskan memiliki sikap ramah dalam membantu mahasiswa mencari solusi untuk memilah jadwal yang bertabrakan, di Fakultas Ekonomi hasil yang diperoleh dari bahwa untuk dimensi empati masih memiliki gap negatif. Untuk rerata keseluruhan dari keseluruhan item, dimensi empati memperoleh gap sebesar -0,59, dengan atribut yang memiliki kesenjangan tertinggi sebesar -0,74 pada Keramahan karyawan membantu mahasiswa mencari solusi untuk memilah jadwal yang bertabrakan.

Rata-rata kesenjangan dari keseluruhan atribut dimensi bukti fisik diperoleh nilai sebesar -0,45, berbeda dengan empat dimensi sebelumnya, dalam dimensi bukti fisik terdapat item yang memiliki kesenjangan negatif yang sangat signifikan yaitu pada ketersedian kursi diruang tunggu, atribut tersebut harus memperoleh prioritas perbaikan dalam dimensi bukti fisik.
Tabel 14.

Perhitungan Gap Performance-Importance

(Gap P-I) Layanan Kinerja Karyawan Administrasi Akademik Dimensi Bukti Fisik

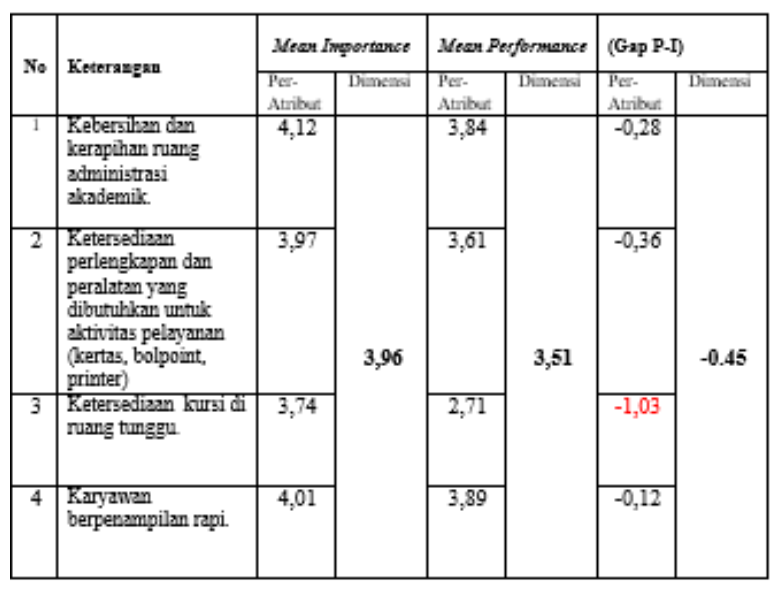

Tabel 15 Rata-rata Keseluruhan Gap Performance-Importance (Gap P-I) Pelayanan Kinerja Karyawan Administrasi Akademik

\begin{tabular}{|l|c|c|c|}
\hline \multicolumn{1}{|c|}{ Dimensi } & $\begin{array}{c}\text { Mean } \\
\text { Importance }\end{array}$ & $\begin{array}{c}\text { Mean } \\
\text { Performance }\end{array}$ & (Gap P-I) \\
\hline Kehandalan & 3,94 & 3,51 & $-0,43$ \\
\hline Daya Tanggap & 3,88 & 3,26 & $-0,62$ \\
\hline Jaminan & 3,89 & 3,38 & $-0,51$ \\
\hline Empati & 3,88 & 3,29 & $-0,59$ \\
\hline Bulcti Fisil & 3,96 & 3,51 & $-0,45$ \\
\hline $\begin{array}{l}\text { Rata-rata } \\
\text { Keseluruhan }\end{array}$ & $\mathbf{3 , 9 1}$ & $\mathbf{3 , 3 9}$ & $\mathbf{- 0 , 5 2}$ \\
\hline
\end{tabular}

Berdasarkan tabel 14 tentang pelayanan karyawan administrasi akademik maka dapat diketahui bahwa semua dimensi memiliki nilai negatif, dengan nilai kesenjangan tertinggi ada pada dimensi daya tanggap sebesar -0,62, sementara itu untuk analisis gap P-I per atribut diperoleh penilaian terendah ada pada atribut Ketersediaan kursi di ruang tunggu yaitu mendapat nilai sebesar $-1,03$.

Rangkuman hasil analisis penilaian gap PI kualitas layanan administrasi akademik untuk lima dimensi SERVQUAL menunjukan bahwa kualitas pelayanan administrasi akademik di Fakultas Ekonomi UBJ dirasa mahasiswa sudah baik, dengan hasil rata-rata kesenjangan -0,52 untuk pelayanan administrasi akademik, 
meskipun dari pengukuran hasil penelitian yang membandingkan antara rata-rata performance dan importance nilai kesenjangan dari kelima dimensi dari masing-masing pelayanan menghasilkan nilai gap negatif, akan tetapi menurut Parasuraman (1991) Jika hasil kesenjangan dibawah -1 berarti baik, dan hasil kesenjangan diatas $\mathbf{- 1}$ berarti kualitas pelayanan yang diberikan tidak baik. Pada prinsipnya data yang diperoleh melalui instrumen SERVQUAL dipergunakan untuk menghitung skor kesenjangan dari rata-rata dimensi by dimensi analysis kualitas jasa layanan administrasi akademik.

Setelah diketahui penilaian tingkat kesesuaian dan nilai gap P-I, selanjutnya penelitian ini akan menggunakan analisis IPA untuk mengetahui pemetaan prioritas layanan, diagram kartesius merupakan gambar yang akan memetakan atribut apa saja yang masuk kedalam kuadran A,B,C dan D.

\section{Importance-performance Analysis (IPA)}

Analisis importance-performance dilakukan dengan cara menghitung nilai ratarata untuk setiap atribut pernyataan dari variabel importance maupun variabel performance. Atribut layanan administrasi akademik yang oleh mahasiswa dianggap penting namun hasil pengukurannya menurut mahasiswa masih berkinerja kurang baik memerlukan perhatian yang lebih dari pihak manajemen pendidikan tinggi dibandingkan dengan atribut layanan yang kurang dianggap penting oleh mahasiswa. Adanya gap yang besar dari performance importance dapat dipakai sebagai gambaran bagi pihak pengelola Fakultas Ekonomi untuk memfokuskan sumber daya-nya dan memprioritaskan perbaikan pada atribut layanan yang memerlukan tindakan perbaikan. Analisis pemetaan prioritas dalam penelitian ini dilakukan terhadap semua responden. Dari olah data menggunakan SPSS 22 diperoleh gambar diagram kartesius IPA untuk seluruh responden mahasiswa terhadap pelayanan administrasi akademik di Fakultas Ekonomi UBJ dapat dilihat dihalaman berikutnya.

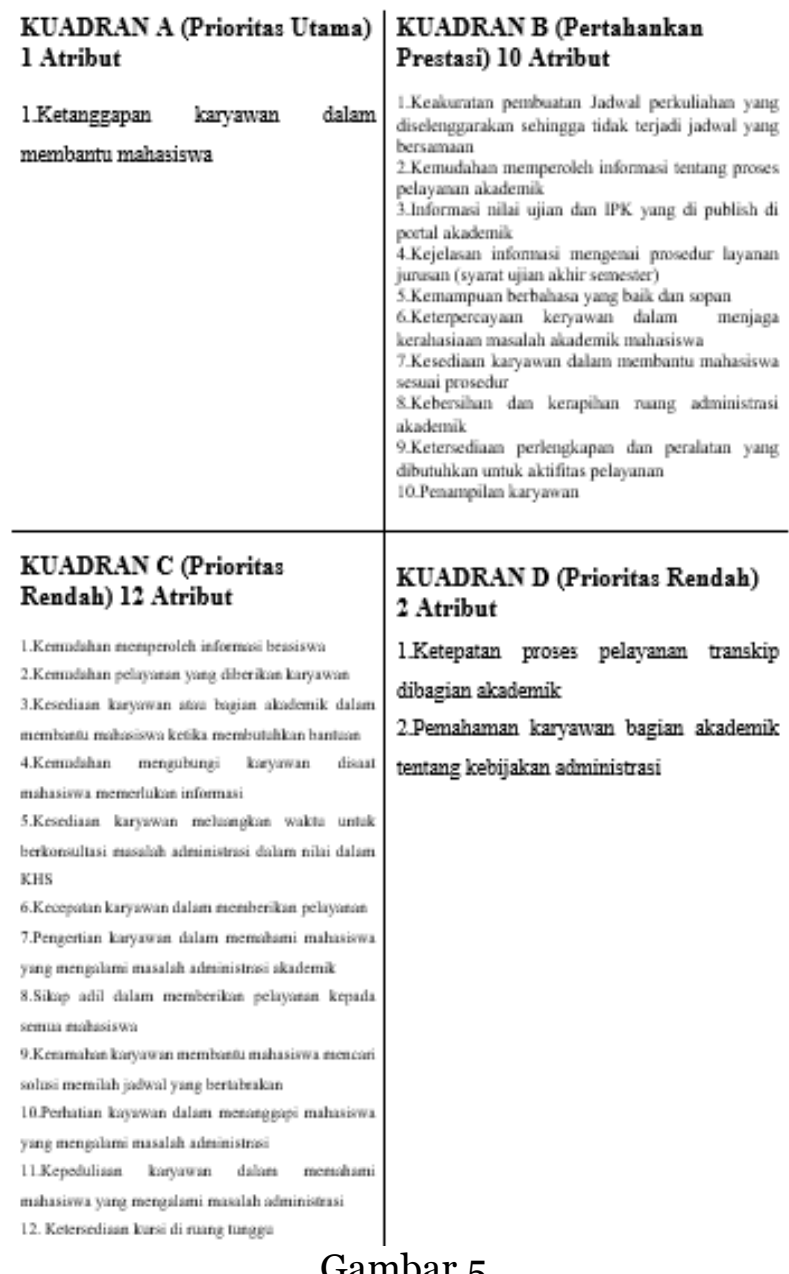

IPA Pelayanan Administrasi Akademik

Untuk pelayanan administrasi akademik di Fakultas Ekonomi UBJ dapat terlihat pada gambar diagram kartesius diatas, dimana gambar menunjukan bahwa sebagian besar atribut menurut responden lebih banyak ada di kuadran C yaitu dua belas (12) atribut, pada kuadran B ada sepuluh (10) atribut, pada kuadran D ada dua (2) atribut dan pada kuadran A ada satu (1) atribut.

Analisis Tingkat Kesesuaian Importance dan Performance Kualitas Pelayanan Administrasi Akademik Fakultas Ekonomi UBJ 
Berdasarkan data hasil penelitian secara keseluruhan untuk kualitas pelayanan Administrasi Akademik Fakultas Ekonomi UBJ dilihat dari kualitas pelayanan (reliability, responsiveness, assurance, emphaty, and tangible) memiliki kinerja sudah baik menurut mahasiswa, hal ini ditunjukan dengan jumlah rata-rata untuk kelima dimensi sama dengan atau lebih dari nilai cut off point yang telah ditentukan. Meskipun pada kenyataanya masih ada item atribut yang nilai tingkat kesesuaian menunujukan kepentingan > tingkat penilaian atau dapat dikatakan bahwa Expected Sevice > Perceived Service, dengan nilai rata-rata tingkat kepentingan mahasiswa terhadap pelayanan administrasi $(3,91)$ lebih besar dibandingkan dengan nilai rata-rata kinerja $(3,39)$. Sehingga hal ini menunjukan keadaan bahwa pelayanan yang diberikan karyawan administasi akademik di Fakultas Ekonomi masih perlu adanya perbaikan.. Berdasarkan persen kesesuain ratarata semau dimensi bahwa masih terdapat ada 9 atribut layanan yang nilai kesesuaiannya masih dibawah $87 \%$.

Kualitas pelayanan Administrasi Akademik yang baik semakin meneguhkan posisi srategis Fakultas Ekonomi sebagai rujukan dalam sektor pelayanan administrasi. Kualitas pelayanan administrasi akademik di kelima dimensi SERVQUAL akan membantu fakultas mengatasi tantangan dan meningkatnya kesadaran dan tuntutan dari masyarakat akan kualitas pelayanan pada pendidikan tinggi. Kualitas pelayanan ini harus terus dievaluasi dan diperbaiki karena penyelenggaraan Fakultas Ekonomi menyadari bahwa kecepatan peningkatan mutu penyelenggaraan pelayanan tidak selalu sebanding dengan peningkatan tuntutan masyarakat.

\section{Kesenjangan Administrasi Ekonomi UBJ \\ Kualitas Akademik \\ Pelayanan Fakultas}

Berdasarkan hasil penelitian analisis gap P-I kualitas layanan Administrasi Akademik untuk lima dimensi SERVQUAL menunjukan bahwa pelayanan admnistrasi akademik dengan nilai gap tertinggi ada pada dimensi kehandalan (reliability) dengan nilai gap -0,62, sedangkan kesenjangan dengan nilai gap terendah ada pada dimensi kehandalan dengan nilai gap o,43. Rata-rata keseluruhan dimensi Pelayanan Administrasi Akademik memiliki nilai negatif 0,52 yang berarti kinerja dari pelayanan Fakultas Ekonomi UBJ menurut persepsi mahasiswa sudah baik, karena nilai rata-rata dari kelima dimensi SERVQUAL kualitas layanan administrasi akademik Fakultas Ekonomi UBJ memiliki nilai dibawah -1 sesuai dengan teori Parasuraman (1991), Jika hasil kesenjangan dibawah -1 berarti baik, dan hasil kesenjangan diatas -1 berarti kualitas pelayanan yang diberikan tidak baik. Akan tetapi perbaikan harus tetap diprioritaskan karena nilai kesenjangan yang menunjukan keseluruhan bernilai negatif, yang berarti masih ada item yang dirasa mahasiswa belum sesuai harapan.

Hasil penelitian tersebut sesuai dengan teori (Parasuraman 1985 dalam Suzanto 2011) menyatakan bahwa kualitas jasa dikatakan baik apabila jasa yang diterima melebihi apa yang diharapkan. Sebaliknya, kualitas jasa akan dikatakan kurang baik jika jasa yang diterima lebih rendah dari apa yang diharapkan. Hal ini karena kualitas jasa yang dipengaruhi oleh expected service dan perceived service.

\section{Atribut Prioritas Kepentingan Dan Usulan Prioritas Tindakan Untuk Meningkatkan Kualitas Pelayanan Administrasi akademik}

Dalam hasil penelitian, diagram IPA digunakan untuk menggambarkan posisi faktorfaktor yang memetakan tingkat kepentingan bagi mahasiswa. Hasil menunjukan hanya 1 faktor masuk kedalam kuadran A, dimana faktor tersebut yang menjadi prioritas perbaikan utama yang harus dilaksanakan sesuai harapan mahasiswa, karena faktor tersebut dianggap sangat penting namun kinerjanya masih belum sesuai dengan harapan.

Pada usulan prioritas perbaikan berdasarkan identifikasi faktor kualitas layananan yang dianggap paling penting oleh mahasiswa, peneliti akan menjabarkan 
implikasi manajerialnya secara keseluruhan pada kuadran A, dan B sehingga tidak terjadi penilaian secara subjektif, yang keterkaitan antara hasil penelitian sesuai analisis kesenjangan, kesesuaian secara keseluruhan dari mahasiswa Program Studi Manajemen FE UBJ yang telah dijabarkan sebelumnya. Hal tersebut diharapkan akan menjadi masukan untuk Fakultas Ekonomi yang diruntut berdasarkan pemetaan prioritas berdasarkan berdasarkan Importance-Performance Analysis.

\section{KESIMPULAN}

1. Tingkat Kesesuaian Importance dan Performance Kualitas Pelayanan Administrasi Akademik Fakultas Ekonomi UBJ. Berdasarkan data hasil penelitian secara keseluruhan untuk kualitas pelayanan Administrasi Akademik Fakultas Ekonomi UBJ dilihat dari kualitas pelayanan (reliability, responsiveness, assurance, emphaty, and tangible) memiliki kinerja sudah baik menurut mahasiswa, hal ini ditunjukan dengan jumlah rata-rata untuk kelima dimensi sama dengan atau lebih dari nilai cut off point yang telah ditentukan. Meskipun pada kenyataanya masih ada item atribut yang nilai tingkat kesesuaian menunujukan kepentingan $>$ tingkat penilaian atau dapat dikatakan bahwa Expected Sevice > Perceived Service, dengan nilai rata-rata tingkat kepentingan mahasiswa terhadap pelayanan administrasi $(3,91)$ lebih besar dibandingkan dengan nilai rata-rata kinerja $(3,39)$. Sehingga hal ini menunjukan keadaan bahwa pelayanan yang diberikan karyawan administasi akademik di Fakultas Ekonomi masih perlu adanya perbaikan. Berdasarkan persen kesesuain rata-rata semua dimensi bahwa masih terdapat ada 9 atribut layanan yang nilai kesesuaiannya masih dibawah $87 \%$. Atribut dalam Dimensi Daya Tanggap (Responsiveness): Kemudahan Pelayanan yang diberikan karyawan, Kesediaan karyawan atau bagian akademik dalam membantu mahasiswa ketika membutuhkan bantuan, Ketanggapan karyawan dalam membantu mahasiswa, Kemudahan menghubungi karyawan disaat mahasiswa memerlukan informasi, Kesediaan karyawan meluangkan waktu untuk berkonsultasi masalah administrasi dalam nilai dan KHS. Atribut dalam Dimensi Empati (Emphaty): Kesediaan karyawan dalam membantu mahasiswa sesuai prosedur, Keramahan karyawan membantu mahasiswa mencari solusi untuk memilah jadwal yang bertabrakan, Perhatian karyawan menanggapi masalah mahasiswa, seperti nilai yang belum keluar karena kesalahan teknis, Kepedulian karyawan dalam memahami mahasiswa yang mengalami masalah administrasi

2. Kesenjangan Antara Persepsi dan Harapan Mahasiswa terhadap Pelayanan Administrasi Akademik pada Fakultas Ekonomi UBJ. Berdasarkan hasil penelitian analisis gap P-I kualitas layanan Administrasi Akademik untuk lima dimensi SERVQUAL menunjukan bahwa pelayanan administrasi Akademik dilihat dari per-dimensi Kualitas Pelayanan mempunyai gap yang tinggi di Fakultas Ekonomi, dengan nilai gap tertinggi ada pada dimensi Daya Tanggap (Responsiveness) sebesar -0,62. Sedangkan rata-rata secara keseluruhan dimensi -0,52 untuk pelayanan administrasi akademik, yang berarti kinerja dari pelayanan Administrasi Akademik Fakultas Ekonomi UBJ menurut persepsi mahasiswa sudah baik, karena nilai rata-rata dari kelima dimensi SERVQUAL kualitas layanan Administrasi Akademik pada Fakultas Ekonomi UBJ memiliki nilai dibawah -1 sesuai dengan teori Parasuraman (1991), akan tetapi untuk rata-rata per-item atribut masih ada satu item atribut yang memilki nilai kesenjangan lebih dari -1 yaitu atribut ketersediaan kursi diruang tunggu.

3. Atribut Pelayanan Administrasi Akademik yang Dianggap Penting oleh Mahasiswa Sesuai dengan Lima Dimensi SERVQUAL. 
Atribut yang berada pada kuadran A berdasarkan hasil penelitian merupakan atribut layanan yang penting dan mendapat penilaian paling tinggi Importance-nya. Atribut yang termasuk dalam kuadran ini adalah atribut Ketanggapan karyawan dalam membantu mahasiswa. Hal ini bukan berarti bahwa atribut kualitas layanan yang berada dalam kuadran B, C, dan D menjadi tidak penting, namun pengelola harus lebih fokus mengalokasi sumber daya perbaikan dalam kuadran A.

\section{SARAN}

1. Berdasarkan hasil penelitian dan kesimpulan yang telah diuraikan, peneliti menemukan beberapa indikasi kelemahan tentang pelayanan Administrasi Akademik pada Fakultas Ekonomi UBJ. Oleh karena itu, ada beberapa hal yang perlu diperhatikan dalam rangka meningkatkan pelayanan Administrasi Akademik pada Fakultas Ekonomi UBJ.

2. Adanya peningkatan pelayanan dalam dimensi keandalan, dalam hal ini dimensi keandalan memiliki nilai gap negatif, sehingga perlu adanya perbaikan, dan evaluasi dalam jangka waktu tertentu, terutama dalam meningkatkan pelayanan administrasi akademik dalam komunikasi dengan mahasiwa.

3. Adanya peningkatan pelayanan dalam dimensi daya tanggap, dalam meningkatkan kesediaan karyawan untuk membantu para mahasiswa dan menyampaikan pelayanan secara cepat . Bisa bermakna kesediaan membantu, dan mengatasi keluhan yang diajukan mahasiswa agar dapat sesuai dengan harapan mahasiswa. Tindakan untuk atribut prioritas (Ketanggapan Karyawan dalam membantu Mahasiswa) diantaranya melakukan Pelatihan Soft Skill terhadap staff karyawan bagian front office FE UBJ tentang Service Excellent, dan perlunya peningkatan sistem pelayanan secara digital untuk mempermudah staff karyawan Fakultas Ekonomi UBJ membantu mahasiswa secara efektif dan efisien.

4. Adanya peningkatan pelayanan dalam dimensi jaminan, misalnya meyakinkan keragu-raguan mahasiswa dengan memiliki kompetensi, kesopanan, kredibilitas agar bisa sesuai dengan harapan mahasiswa, hal ini bisa dilakukan salah satunya dengan menjamin kerahasiaan data mahasiswa baik nilai ataupun masalah yang sedang dihadapi.

5. Kurangnya ketersediaan kursi tunggu menjadi salah satu pelayanan dari bukti fisik yang dikeluhkan mahasiswa pada Fakultas Ekonomi UBJ, sehingga perlu adanya peningkatan serta perbaikan penampilan fasilitas, peralatan , dan bahan sarana komukasi yang dimiliki oleh fakultas agar dapat sesuai dengan harapan pelanggan dalam hal ini mahasiswa.

\section{DAFTAR PUSTAKA}

Alma, Buchari. (2003). Pemasaran Strategi Jasa Pendidikan. Bandung: Alfabeta.

Alma, Buchari. (2013). Manajemen Pemasaran dan Pemasaran Jasa. Edisi 2. Bandung: Alfabeta.

Anggraeni, L. D., Deoranto, P., \& Ikasari, D. M. (2015). Analisis persepsi konsumen menggunakan metode importance performance analysis dan customer satisfaction index. Industria: Jurnal Teknologi dan Manajemen Agroindustri, 4(2), 74-81.

Arikunto, S. (2006). Prosedur Penelitian: Suatu Pendekatan Praktik. Jakarta: Rineka Cipta.

Berry, L. L., \& Parasuraman, A. (2004). Marketing services: Competing through quality. Simon and Schuster

Diyahya, I., Sukiyono, K., \& Badrudin, R. (2016). Analisis Tingkat Kepuasan Petani Jagung Terhadap Pelayanan Lembaga Pemasarannya Di Kecamatan Lubuk Pinang Kabupaten Mukomuko. Jurnal AGRISEP: Kajian Masalah Sosial Ekonomi Pertanian dan Agribisnis, 15(1), 45-58

Djunaidi, M., Alghofari, A. K., \& Rahayu, D. A. (2006). Penilaian kualitas jasa pelayanan lembaga bimbingan belajar primagama berdasarkan preferensi 
konsumen. Jurnal Ilmiah Teknik Industri, 5(1), 25-32.

Fakultas Ekonomi UBJ Website, Profil Tentang Fakultas Ekonomi http://fe.ubharajaya.ac.id/tentangfakultas-ekonomi/ (Diakses tanggal 15 Juni 2019)

Jienardy, C. (2017). Gap analisis persepsi dan ekspektasi konsumen terhadap kualitas layanan, harga, kualitas produk Esus. PERFORMA, 1(6), 703710.

Kaihatu, T. S. (2008). Analisa kesenjangan kualitas pelayanan dan kepuasan konsumen pengunjung Plaza Tunjungan Surabaya. Jurnal Manajemen dan Kewirausahaan, 10(1), 66-83.

Khoirista, A. (2015). Pengaruh Kualitas Pelayanan Terhadap Kepuasan Pelanggan (Survey Pada Pelanggan Fedex Express Surabaya). Jurnal Administrasi Bisnis, 25(2)

Munawaroh, M. (2005). Analisis pengaruh kualitas jasa terhadap kepuasan pada industri pendidikan di Yogyakarta. Jurnal Fakultas Hukum UII.

Nugraha, N., Nasution, A., \& Amaranti, R. (2016). Pengembangan Model Services Quality Untuk Peningkatan Kualitas Layanan Akademik Internal di Perguruan Tinggi. ETHOS (Jurnal Penelitian dan Pengabdian), 191-198.

Nugroho, W., \& Prawoto, M. A. (2018). Analisis Kepuasan Peserta Terhadap Kualitas Pelayanan WIDYAISWARA Pada DTSS Pengadaan Barang/Jasa Di BDK Malang. Jurnal Pendidikan Nonformal, 12(2), 62-

Pakpahan, S. P. (2004). Persepsi mahasiswa UPBJJ-UT Medan tentang pelayanan akademik dan non-akademik yang diberikan oleh UPBJJ-UT Medan. Jurnal pendidikan terbuka dan jarakjauh, 5(1), 47-58

Panjaitan, J. E., \& Yuliati, A. L. (2016). Pengaruh Kualitas Pelayanan Terhadap Kepuasan Pelanggan Pada JNE Cabang
Bandung [The Influence of Service Quality on Customer Satisfaction at JNE Branch in Bandung]. DeReMa (Development Research of Management): Jurnal Manajemen, 11(2), 265-289.

Parasuraman, A., Zeithaml, V. A., \& Berry, L. L. (1985). A conceptual model of service quality and its implications for future research. Journal of marketing, 49(4), 41-50.

Parasuraman, A, Valerie A. Zeithaml, Leonard L. Berry. (1998). SERVQUAL : A Multiple Item Scale For Measuring Consumer Perception Of Service Quality. Journal of Retailing Vol. 64 No. 1, pp 12-37.

Rahareng, Jennifer Vinny, dan Relawan nurnida. (2017). Pengaruh Kualitas Pelayanan Akademik Terhadap Kepuasan Mahasiswa (Studi pada Mahasiswa Administrasi Bisnis Universitas Telkom). Jurnal AdBispreneur Vol. 2, No. 2, Agustus 2017 Hal. 125-133

Rosi, Setyorini. (2015)."Persepsi Mahasiswa Terhadap Kualitas Layanan Di Program Magister Sains dan Doktor Fakultas Ekonomika Dan Bisnis Universitas Gadjah Mada: Penerapan Model Servqual Gap-5 Dan IPA".Yogyakakarta: Tesis UGM

Rosita, T., Santi D., Susanti, dan Nurhasanah. (2011). Pedoman Penyelenggaraan Program pascasarjana. Edisi Kedua, Cetakan Ketiga. Jakarta: Penerbit Universitas Terbuka.

Sigit, P., Dimas, R., \& Oktafani, F. (2014). Pengaruh Kualitas Pelayanan Terhadap Kepuasan Pelanggan Pengguna Jasa Lapangan Futsal (Studi Kasus Pada IFI Futsal Bandung). Jurnal. Universitas Telkom.

Sindo News. (2017, 6 November). Mendikbud: Pendidikan Indonesia Alami KemajuanSignifikan.https://nasional. sindonews.com/read/1254817/144/me ndikbud-pendidikan-indonesia-alami- 
kemajuan-signifikan1509938303.Diakses 17 Feberuari 2019.

Sugiyono. (2016). Metode Penelitian Kuantitatif, Kualitatif dan $R \& D$. Bandung: PT Alfabeta

Suzanto, B. (2011). Pengaruh Kualitas Jasa Pelayanan Terhadap Kepuasan Pasien Pada Rumah Sakit Umum Kota Banjar. Jurnal Ekonomi, Bisnis \& Entrepreneurship, 5(1), 28-44.

Thtersia Ifi Wilis. 2015. "Analisis Kualitas Pelayanan Dengan Menggunakan Gap Analysis dan IPA Pada Restoran Fusion Food". UGM: Skripsi

Tjiptono,Fandy. (2011). Pemasaran Jasa. Malang: Banyumedia

Triono, M. J. (2012). Kepuasan Mahasiswa Terhadap Layanan Administrasi Akademik Fakultas Tarbiyah Iain Walisongo Semarang (Doctoral dissertation, IAIN Walisongo)

Utami, I. A. I. S., \& Jatra, I. M. (2015). Pengaruh kualitas layanan terhadap kepuasan pelanggan restoran Baruna Sanur. EJurnal Manajemen Universitas Udayana, 4(7)

Wulan, S., \& Susanto, F. (2013). Hubungan Persepsi Konsumen Tentang Lokasi Usaha dengan Keputusan Pembelian pada UD Sinar Fajar Cabang Antasari di Bandar Lampung. Jurnal Manajemen dan Bisnis, 4(1). 

25 |Analisis Kualitas Pelayanan Administrasi Akademik Dengan Metode Importance Performance Analysis (IPA) (Studi Fakultas Ekonomi Universitas Bhayangkara Jakarta Raya) 